\title{
Review
}

\section{The city on the hill from below: The crisis of prophetic Black politics}

\author{
Stephen H. Marshall \\ Temple University Press, Philadelphia, 2011, x+235pp., \$27.95, \\ ISBN: 978-1439906569 \\ Contemporary Political Theory (2014) 13, e7-e9. doi:10.1057/cpt.2013.7
}

Stephen Marshall's engaging book, The City on the Hill from Below, argues that prophetic political critique is in crisis. This once-potent tradition in African American political thought now 'appears to have been silenced despite the prolonged afterlife of slavery and Jim Crow' (p. 170). To remedy this loss, Marshall skillfully reconstructs the African American prophetic tradition as a genre of political theory that provides 'critical insights into the most intractable questions of American political life' (p. 3). Offering insightful readings of the tradition's most profound prophets David Walker, Frederick Douglass, W.E.B. Du Bois and James Baldwin - Marshall shows how each thinker "conceived the problems of slavery, segregation, and other forms of white supremacy as critical national questions that demanded a decision whose continued deferral ... would result in disaster for the polity' (p. 19).

'For we must consider that we shall be as a city on a hill. The eyes of all people are upon us'. John Winthrop's invocation is often trotted out as the founding moment of American exceptionalism. Marshall, however, offers a more complex reading: Winthrop condensed a political theology into a phrase that 'unites a conception of community, a mode of belonging, and a sense of historical destiny' (p. 4), thus linking 'institutional conditions for collective self-determination to the fulfillment of a divine mandate' (p. 5). Marshall argues that this enduring image is best understood as constituting a 'political imaginary that founds and sustains a unique and enduring solidarity within the American polity ... that unites political desire with religious hope' (p. 2). But none of this is new.

What is original is Marshall's contention that Winthrop's 'exceptionalist account of Christian solidarity produced and legitimated political evil' (p. 22). To explicate this claim, he draws on St. Augustine, who, Marshall insists, 'advanced an account of political evil particularly useful for an understanding of the institutionalization of Winthrop-inspired public practices of mercy in the New World' (p. 21). Augustine had cautioned that 'self-sacrifice on the basis of resemblance constituted a criminal solidarity' (p. 21). Winthrop's Biblical commonwealth, then, is rooted in a Christian 
solidarity that had the adverse consequences of exclusions and oppression. This solidarity was 'criminal' precisely because it denied communal and covenanted membership to Native Americans and African Americans, further authorizing genocide, slavery, White supremacy and other forms of racial domination. As a result, prophetic political critics were 'forced to grapple seriously and productively with the problem of political evil' (p. 19).

This argument unfolds through critical interpretations of central figures in the African American prophetic tradition: Walker, Douglass, Du Bois and Baldwin. With his reading of each theorist, Marshall also aims to illuminate a distinct register of Black politics. First, he views Walker as centrally concerned with political ignorance as both consequence and precondition of slavery, a fear that highlights the cognitive cost and effect of domination. Second, he turns to more formal political arenas when arguing that Douglass's institutionalism is borne out of the conviction that slavery threatens to corrupt the polity. Third, Marshall argues that Du Bois identified how de facto subordination and relations of domination in the private sphere sustain White supremacy. Du Bois was therefore doubtful 'that the capitalist market would foster the kind of virtues necessary for black politics' (p. 98) and instead 'sought to empower black intellectual elites to solve American problems of race ...' (p. 176). Baldwin is the final thinker Marshall takes up, arguing that Baldwin's 'faith lay in art as a social power that could facilitate ... courageous self-examination' (p. 176). To this end, Baldwin's political aesthetic offered erotic love as both critique and alternative to Winthrop's Christian solidarity. Let us look more closely at two of those prophets: Walker and Douglass.

Marshall views Walker as a political theorist of unparalleled skill. 'In sharp contrast to the exceptionalist self-understanding of American civil-religion ... Walker insists that American Christians have become inured to their own evil' (p. 46). But the more pernicious consequence is enforced ignorance, which was the 'fundamental achievement of the practice of enslavement' (p. 46). Because political ignorance makes African Americans 'systematically misidentify their true interests' (p. 41), freedom requires a direct confrontation with the problem of ignorance. Turning to the affective register, Marshall says that Walker sought to 'understand the dispositions inculcated by ignorance, their effects on the character of enslaved and free blacks, and the obstacles they raise to blacks constituting themselves as a free people' (p. 41). In his conclusion, Marshall casually notes that it is clear that 'Walker's political desire was to be a lawgiver, one who destroys old laws and legislates new ones to found a new people' (p. 175). I wish Marshall had pursued this profound insight. His reading of Walker's Appeal against the Constitution could sustain an interpretation of the Appeal as not only social reflection, but also a political intervention that inaugurates a transformation towards the emergence of a 'new subjectivity'. Regardless, Marshall's thoughtful analysis of Walker will certainly provoke a return to the Appeal.

In turning to Douglass, Marshall offers a novel yet familiar reading. He insists that Douglass made 'two central contributions' to political theory. First, Douglass offers a 
'profound analysis of the complex political evils of American slavery' (p. 61) by claiming that the 'will to mastery constituted the chief foundational evil, producing white supremacy along with other oppressive practices' (p. 90). Second, Douglass articulates 'a compelling vision of authentic American political purposes that featured black freedom as a central constitutive element' (p. 61). He says Douglass believed the 'true enemy was neither the entire American political community nor its powerful civil religion sustained by the imaginary of the City on the Hill. Rather, the true enemy of blacks was the ... "slave power"' (p. 60). Douglass, in short, held the view that "white supremacy eviscerated commitments to natural rights and political equality' (p. 59). In other words, Marshall wants to root Douglass's second and more familiar contribution - Douglass's desire to perfect the Constitution - in a meditation on slavery and White supremacy as political evil, what Marshall offers as Douglass's first but lesser known contribution to political theory. But those who interpret Douglass as a liberal constitutionalist will insist that his condemnation of slavery is anchored in normative commitments to liberalism rather than a concern with evil.

Marshall's book has many virtues, one of which is its seamless explication of the broader political critiques etched in the grooves of particular narratives. His ability to navigate multiple genres - appeal, slave narrative, autobiography and literature - will make his book generative for the study of Black and American political thought, where theorizing often arises from the tumble of politics and takes on a more vernacular and democratic voice. Some readers will wonder whether a metaphor even a powerful and enduring one - can do the theoretical lifting Marshall demands of the 'city on the hill'. Others may ask if Marshall considers the fact that most nineteenth-century American thinkers used scripture to limn rather than structure their arguments. But most will come away from reading The City on the Hill from Below convinced that it is only from the vantage point of Black political thought that the contours of the American political tradition come into focus.

Desmond Jagmohan Cornell University, Ithaca, NY 14853, USA 